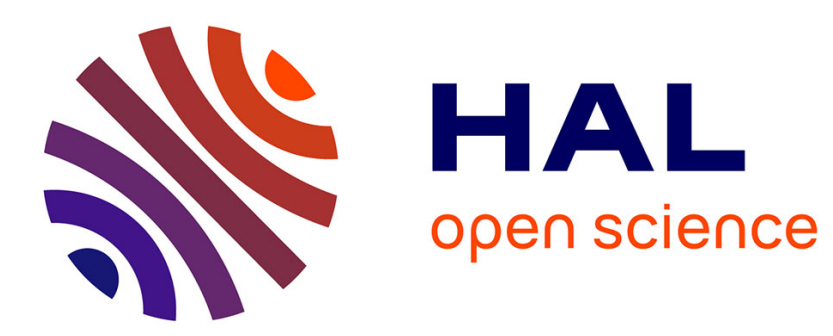

\title{
The institutional failures of International Monetary Fund conditionality
}

Jean-Pierre Allegret, Philippe Dulbecco

\section{To cite this version:}

Jean-Pierre Allegret, Philippe Dulbecco. The institutional failures of International Monetary Fund conditionality. Review of International Organizations, 2007, 2 (4), pp.309-327. halshs-00238490

\section{HAL Id: halshs-00238490 \\ https://shs.hal.science/halshs-00238490}

Submitted on 27 Mar 2009

HAL is a multi-disciplinary open access archive for the deposit and dissemination of scientific research documents, whether they are published or not. The documents may come from teaching and research institutions in France or abroad, or from public or private research centers.
L'archive ouverte pluridisciplinaire HAL, est destinée au dépôt et à la diffusion de documents scientifiques de niveau recherche, publiés ou non, émanant des établissements d'enseignement et de recherche français ou étrangers, des laboratoires publics ou privés. 


\title{
The Institutional Failures of International Monetary Fund Conditionality
}

\author{
J.P. Allegret \\ Associate Professor of Economics \\ at the University of Lumière Lyon 2 \\ École Normale Supérieure Lettres et Sciences Humaines GATE - CNRS \\ Bureau R131 15, Parvis René Descartes BP 700069342 Lyon cedex 07 FRANCE \\ allegret@gate.cnrs.fr \\ Ph. Dulbecco \\ Professor of Economics \\ at the University of Auvergne Clermont 1 \\ CERDI - 65 boulevard François Mitterrand, 63000 Clermont Ferrand, France \\ philippe.dulbecco@cerdi.u-clermont1.fr
}

The Review of International Organizations 2, 4 (2007) pp. 309-327

\begin{abstract}
The conditionality employed by the International Monetary Fund (IMF) in its lending policy is one of the main themes of controversy in the debate on the new international financial architecture. The purpose of this paper is to propose an analytical framework integrating the diverse explanations of the failure of IMF conditionality. Our analysis is based on the idea that the IMF is a key player in the running of markets in a global economy. More precisely, we explain that most of the criticisms concerning conditionality should be analyzed through what we agree to call the institutional failures of IMF conditionality. These institutional failures must be appreciated at two complementary levels: the first level refers to the intrinsic bureaucratic bias of the IMF while the second deals with the inability of the IMF to manage the institutional change required for the development of market processes and hence to maintain the institutional order in recipient countries. Although the first level failures have been particularly well studied via the international public choice approach, those of the second are, at best, often reduced to a simple statement. However, analyzing both levels of institutional failure of the IMF together is not without implications for the way in which the reforms of conditionality are conceived. Indeed, by including an analysis of the second level of failures, i.e. those relating to the relationship between conditionality and domestic institutional change, the recommendation of ex-ante conditionality emanating from the public choice approach, which tackles the first level of failures, will be invalidated. Instead a new approach will be proposed that suggests the separation of the role of the IMF as financial backer from its role as adviser to countries confronted by the globalization process.
\end{abstract}

JEL codes: F3; N2

\footnotetext{
- A previous version of this paper was presented at the Public Choice Annual Meeting, Baltimore (US), March 11-14 2004 and at the European Public Choice Meeting, Berlin (G), April 15-18 2004. We would like to thank all participants for their remarks and suggestions. The paper benefited greatly from careful readings by the two referees of the review and the editor Axel Dreher. We thank Pauline Boerma-Collier for her very useful assistance. Usual caveats apply.
} 


\section{The Institutional Failures of International Monetary Fund Conditionality}

\section{Introduction}

Conditionality is a central feature of the IMF's activities. Broadly defined, it is "a mechanism that links financing and policies" (IMF, 2001a: 4). Conditionality specifies policies, performance criteria and standards which borrowing countries must satisfy to receive resources from the Fund.

Although conditionality was initially a vaguely expressed concept in the Bretton Woods Agreements, it developed during the 1950s with the expansion of IMF's lending activities, and more particularly after 1979. During the 1980s and 1990s, the IMF was confronted by increasingly complex problems such as the debt crisis of developing countries, the transition of socialist countries to market economies, and the increased influence of global capital markets. Consequently, binding conditions attached to IMF agreements became ever more sophisticated and numerous. "The mean value of the average number of binding conditions for arrangements initiated between 1952 and 1973 was 4.23; between 1974 and 1982 was 7.13; between 1983 and 1990 was 12.07 and between 1991 and 1995/2000 was 12.42” (Gould, 2001: 6) ${ }^{1}$. This trend has been accompanied by two developments.

The first is that the IMF has exerted a growing influence on domestic affairs. The increasing use of procedural conditionality, instead of target conditionality, is a clear illustration of this process. Targets refer to measures - such as a fiscal deficit limit - that can be met by borrowing countries in whatever way they choose. Procedures specify both ends and means by requiring countries to implement a single onetime action, for example a change in exchange rate regime or the adoption of new corporate governance principles. One consequence is that "procedures more directly dictate borrowing country policies, constrain domestic politicians and violate sovereignty” (Gould, 2001: 8) ${ }^{2}$. The second development, as noted by Kapur and Webb (2000), is that the IMF has introduced more and more governancerelated conditionality in its programs. The point is that this new form of conditionality implies the need for institutional change in countries under IMF programs. It is a clear departure from the original purpose of conditionality. Indeed, conditionality was initially a tool to protect the financial integrity of the IMF, whose intent is to provide financial resources to member

\footnotetext{
${ }^{1}$. See also, Goldstein (2000) and IMF (2001a) for statistical data.

${ }^{2}$. After 1982, a steady increase in procedural conditionality can be observed.
} 
countries with balance of payments imbalances ${ }^{3}$. With the increasing number of conditions, the IMF has become more and more involved in micro-management whereas, initially, it was focused on its core areas, that is, monetary and fiscal macroeconomic issues. The link between IMF lending and balance of payments problems is increasingly less obvious.

Although conditionality is now at the heart of the IMF's activities, it is also one of the main areas of controversy in the debate on the new international financial architecture. Indeed, even if the IMF were successful in protecting its financial integrity (bearing in mind that this was one of the original purposes of conditionality), the poor completion of IMF programs, lead increasing numbers of observers to stress that conditionality is inefficient ${ }^{4}$. The main reasons for such inefficiency are as follows ${ }^{5}$. Firstly, the growing number of monitoring tools used by the IMF renders conditionality too complex and difficult to monitor. The IMF itself admits an "ambiguity about the boundaries of conditionality" (IMF, 2001a: 18). Secondly, the proliferation of conditions, especially structural conditions, makes conditionality too intrusive and costly. As a result, member countries are discouraged from demanding the Fund for assistance. Not only do they contest the political legitimacy of the Bretton Woods institution, but also they wait for a situation to become extreme before resorting to IMF lending. Thirdly, conditionality seems ineffective in inducing policy changes. On the one hand, borrowers do not view the withholding of funds as a credible threat. On the other hand, the effectiveness of conditionality is undermined by difficulties in monitoring compliance. Finally, IMF conditionality suffers from the one-size-fits-all approach. The IMF staff uses best practices and theoretical benchmarks without investing sufficiently in obtaining knowledge of the initial conditions specific to each country, such as domestic political factors and the cultural environment.

The purpose of this paper is to propose an analytical framework forging together these various explanations of the failure of IMF conditionality. Our analysis is based on the idea that the IMF as an institution plays a major role in running the market in the global economy. Indeed,

\footnotetext{
${ }^{3}$. According to Article I of the Articles of Agreement, one of the purposes of the IMF is "to give confidence to members by making the general resources of the Fund temporarily available to them under adequate safeguards, thus providing them with opportunity to correct maladjustments in their balance of payments without resorting to measures destructive of national or international prosperity”. In other words, the original conception of IMF lending was to allow countries to make an adequate trade-off between adjustment and financing.

${ }^{4}$ Mussa and Savastano (2000), for example, studied 615 IMF arrangements over the 1973-1997 period using a sample composed of 5 industrial countries and 121 developing countries. Their main result was that more than a third of IMF programs ended with disbursements of less than half of the support initially agreed to. An extensive empirical literature confirms this poor completion of IMF programs.
}

${ }^{5}$. See Goldstein (2000) and Dreher (2006) for an overview. 
let us recall that the function of any institution is to provide structures that enable players to coordinate their behaviour. Thus institutions provide an essential element for the harmonious functioning of markets. These coordination structures are provided by the IMF to countries engaged in IMF programs, especially through conditionality. Indeed using the mechanism of conditionality, the IMF is implicitly mandated by the international community to push countries that have IMF programs, to implement the institutional reforms and good practices required for participation in the process of market globalisation. Consequently we explain that most of the criticisms addressed at conditionality should be analyzed through what we call the institutional failures of the IMF which, in turn, are a cause of the ineffectiveness of IMF conditionality. These institutional failures must be appreciated at two complementary levels: the first level refers to the intrinsic bureaucratic bias of the IMF while the second deals with the inability of the IMF to manage the institutional change required for the development of market processes and hence to maintain the institutional order in recipient countries. Although the first level failures have been particularly well studied via the international public choice approach, those of the second are, at best, often reduced to a simple statement. However, analyzing both levels of institutional failure of the IMF together is not without implications for the way in which the reforms of conditionality are conceived. Indeed, by including an analysis of the second level of failures, i.e. those relating to the relationship between conditionality and domestic institutional change, the recommendation of ex-ante conditionality emanating from the public choice approach, which tackles the first level of failures, will be invalidated. Instead a new approach will be proposed that suggests the separation of the role of the IMF as financial backer from its role as adviser to countries confronted by the globalization process.

The remainder of the paper is structured as follows. Section 2 analyses the ineffectiveness of IMF conditionality from a public choice perspective. The purpose here is to return to the intrinsic institutional failures of the IMF so as to understand the poor completion of IMF programs. Section 3 makes use of the Austrian theory of institutions in order to appreciate the challenge of the institutional change faced by recipient countries. Section 4 concludes our discussion.

\section{The Ineffectiveness of Conditionality: a Public Choice Approach}

The institutional dimensions of IMF conditionality have been analyzed using the public choice approach. Indeed according to this line of analysis, the efficacy of IMF programs could be altered by focusing on factors which all refer to the institutional failures of the IMF. 
Numerous studies devoted to examining the efficacy of IMF programs highlight, for example, the decisive role of political factors in undermining their success (2.1.). Two other institutional failures are also analyzed: the bureaucratic bias of the IMF on the one hand, and the weak incentives for implementation of conditions on the other (2.2.). The point is that these analyses all point to the need for a specific reform of conditionality based on the idea of pre-conditions (2.3.).

\subsection{The Influence of Political Factors on Conditionality}

Political factors and the efficacy of IMF programs are highly interactive: not only do domestic political factors exert an influence on the completion of IMF's measures, but the IMF is not exempt from taking political factors into consideration when it decides to stop or continue an incomplete program at the end of the initial period of measures.

When considering the interaction between international and domestic institutions to explain the completion of programs, Vreeland (2002) details the way in which governments may use the IMF's leverage to push through unpopular policies. In a similar vein, Edwards (2001) demonstrates that the ability of governments to satisfy IMF conditionality depends on the political system; a fractionalized (divided?) legislative political organization will tend to exhibit poorer performance in fulfilling the aims of IMF programs than a united one.

Ivanova et al. (2006) use an econometric approach to identify factors affecting implementation of IMF-supported programs. Program implementation is measured with different indicators referring to the extent to which the program has been completed without excessive delays, the extent to which conditions have been met, and the extent to which funds have been disbursed by the IMF. The variables that are likely to influence program implementation are as follows: (i) the political characteristics of borrowing countries, (ii) the variables describing the IMF's behavior during program implementation, and (iii) domestic conditions in countries under programs and external conditions affecting them. The authors study 170 IMF programs over the period of 1992-1996. Their main result is that domestic political factors exert a strong influence on program implementation. Program completion is low in countries with strong special interests, lack of political cohesion, inefficient bureaucracies, and ethno-linguistic divisions ${ }^{6}$. Dreher (2003) stresses the influence of elections on the interruption of programs. Using a sample of 104 countries over the period of

\footnotetext{
${ }^{6}$. Studying 77 developing countries between 1975 and 1999, Joyce (2003) shows that successful program implantation is affected by domestic political considerations, notably the degree of democracy, the degree of election competitiveness and the degree of political pluralism.
} 
1975-1998, he shows that the frequency of interruption is higher before elections. This is especially the case in more democratic countries where governments need popular support to win elections. Interestingly, the author shows that elections and democracy interact with each other: the influence of elections on program interruptions decreases correspondingly with the degree of democracy. Assuming that non-compliance of conditions is higher before elections in such regimes, due to the unpopularity of the measures associated with IMF conditions, one can conclude that the Fund is probably more lenient towards democratic regimes.

Dreher and Vaubel (2004a) suggest that IMF assistance facilitates political business cycles in the recipient countries ${ }^{7}$. According to the authors, IMF lending facilitates a pre-election boom $^{8}$ while IMF conditionality is used by domestic authorities to justify post-election recession. According to their results, it appears that monetary expansion and fiscal deficits are larger at the time of elections, and that new net IMF credits are significantly larger immediately before and after elections in democratic countries.

Does the strategy implemented by powerful states in the world economy explain the IMF's decisions to interrupt or continue a program with a member state? The answer specified in the IMF's charter is clear: political factors do not exert any influence. Empirical studies are more mixed in their conclusions. In order to explain why countries get financial assistance from the IMF, Barro and Lee (2005) suggest that the extent of political connections to the IMF appears to be a significant explanatory variable determining the probability and size of IMF loans ${ }^{9}$. Thacker (1999) studies the underlying causes of the IMF's behavior concerning lending decisions and sanctions when borrower compliance with IMF conditionality is weak ${ }^{10}$. His main result is that politics matter in the IMF and consequently there is no guaranty that the deeper integration of the IMF into the domestic political game leads to better outcomes. The IMF, in its decision-making, does not necessarily follow the general interest of the countries concerned, but instead can be influenced by strategies pursued by powerful states in the world economy. According to Dreher and Jensen (2007), the United States exerts a significant

\footnotetext{
${ }^{7}$ Based on a sample of 106 countries that obtained IMF credit over the period of 1971-1997.

${ }^{8}$. For example, governments can use IMF credits to make foreign exchange interventions in order to sustain the exchange rate regimes after a monetary expansion.

9. The determinants of the political connections are the following: country quota, the number of nationals amongst the IMF staff, and member country's political and economic proximity to the IMF's major shareholding countries. Each of these determinants exerts a significant influence on IMF loans.

${ }^{10}$. Decisions to lend are analyzed over the period of 1985-1994 for 87 developing countries.
} 
influence on IMF conditionality ${ }^{11}$. Not only do closer allies of the US enjoy a lower number of conditions than other countries, but also, prior to elections, it appears that IMF conditionality is softer with governments that support US international strategy.

Overall, the influence of political factors on conditionality raises two issues that pose a challenge for the IMF. The first is that it appears to be increasingly necessary to devote sufficient resources “to identify reformers not to create them” (Dollar, Svensson, 2000: 896). The second is that the efficacy of IMF conditionality depends in part on the degree of depoliticization of IMF decisions.

\subsection{The IMF Institutional Failures}

Two institutional failures can be distinguished: those arising from the existence of a bureaucratic bias, in which the activities of the institution do not respond to collective needs but to the maximization of its budget; and those based on the weakness of incentive mechanisms within the IMF and between the IMF and the recipient countries.

A potential bureaucratic bias can emerge from the ability of international institutions to become autonomous and to be powerful actors in global politics. Autonomy is based on knowledge of the functioning of the global economy and leads to an expertise, both technical and informational, that is not shared by international institutions with other actors, mainly states. An illustration of this process is the evolution of conditionality within the IMF. "The development of the principle of conditionality went hand-in-hand with a shift in responsibility from the executive board to the staff” (Martin, 2002: 20).

With the evolution of conditionality, not only does the staff have a significant agenda-setting power, but it also acquires confidential information about the countries' economic situation not transmitted to the executive directors. This evolution constitutes a powerful source of autonomy for the staff. Thus, the staff can use this autonomy to achieve its own preferred objective, that is the maximization of its budget and its size, by changing conditionality over time. The evolution of conditionality is consequently not necessarily linked to changing conditions in the world economy. This hypothesis is confirmed by Dreher and Vaubel (2004b), who explain that the evolution of conditionality seems to be founded not on

\footnotetext{
${ }^{11}$. 38 countries over the period of October 1997-March 2003 are studied. The relationship between the US and the recipient country is identified through voting in the United Nations generally assembly. The two countries are considered as allies when they vote in the same direction.
} 
economic motives, but on the level of demand for IMF credit relative to the IMF quota ${ }^{12}$. Overall, the staff balances the marginal utility of imposing conditions, that is the safeguard of its financial integrity, with the marginal disutility of losing demand for its credit as a consequence of stronger conditions, that is a decrease in its influence.

Two main incentive failures can be distinguished. The first refers to the decision-making process. At this level, Willett (2002) stresses the dependency of staff members, in terms of their careers, on the IMF management ${ }^{13}$ and Executive Board. Political pressures prevent staff members from advising on decisions exclusively founded on economic analysis: IMF lending to Russia is a good example, where political pressures from the major industrial countries led the staff to take decisions that were inefficient from an economic point of view. But bearing in mind management's control over staff careers, it was rational to promote a loan to Russia.

A second incentive failure within the IMF refers to what Svensson (2003) has called the "budget-pressure problem”. In most donor organizations, there is a discrepancy between allocation and disbursement decisions. Generally, allocation decisions are centralized, and depend on guidelines and procedures, while disbursement decisions are decentralized, and are based on specific projects or countries. Consequently organizations exhibit "a strong bias towards 'always' disbursing committed funds to the ex ante designated recipient, irrespective of the recipient government's performance and the conditions in other potential aid recipient countries” (Svensson, 2003: 383). There is no link between the recipient country's efforts to satisfy conditionality and the disbursement of funds ${ }^{14}$.

\subsection{The Reforms of Conditionality from a Public Choice Perspective: Tying the Hands of the} $I M F$

The public choice solution to these inefficiencies of conditionality is to tie ex ante the hands of the IMF. Thus, in the spirit of the Advisory Commission (Meltzer, 2000), Dreher and Vaubel (2004a and 2004b) suggest substituting ex post conditionality by ex ante

\footnotetext{
${ }^{12}$. Their study uses two main statistical sources : a chronological study from 1958 to 1999; an econometric analysis over the period of October 1997-March 2003 for 206 IMF letters of intent concluded with 38 countries. "Conditionality increases when the demand for IMF credit grows relative to quota; (...) conditionality decreases or stagnates when the demand for IMF credit is weak or IMF quotas have been raised” (Dreher, Vaubel, 2004b: 10).

${ }^{13}$. The Managing Director and Deputy Managing Directors.

${ }^{14}$. Svensson (2003) confirms this result using data from around 200 structural adjustment programs from the World Bank over the period of 1980-1995.
} 
conditionality ${ }^{15}$. The main purpose of the latter is to establish the pre-conditions that country members must fulfill in order to be eligible for IMF lending. Pre-conditions reflect the financial soundness of countries, (Meltzer, 2000: 25) that is: (i) the country's commitment to fiscal standards, (ii) a policy of transparency based on the public communication of timely and accurate financial information, (iii) an adequate capitalization of domestic banks, and (iv) authorization for foreign banks to participate in the domestic banking system.

The IMF contingent credit lines (CCL) facility created in 1999 is close to this ex ante conditionality. The CCL facility offers member countries with strong economic policies, a precautionary line of defense against balance of payments problems linked to financial contagion. Countries satisfying pre-conditions could accede to a specified amount of financing automatically available. However since its creation, no country has signed up for pre-approval, and the Executive Board decided not to renew the CCL in November $2003^{16}$. Although the IMF justifies such a decision by stressing the reinforcement of the international financial system, it seems that the CCL has suffered a major breakdown. Indeed, the CCL requires that each member country sign in advance a declaration regarding its potential need for IMF lending. The difficulty lies in the fact that the risk exists that such an official declaration may be interpreted as a negative signal by international markets. The reasoning is as follows: by subscribing to the CCL, a government implicitly announces that it anticipates a crisis and a need for IMF credit. This is why Dreher and Vaubel (2004b) defend the idea that all countries should be eligible for such a facility, without a pre-declaration if they respect the pre-conditions. This effective ex ante conditionality requires both an official mandate and a universal principle.

The main advantage of the ex ante condition could be to reduce political pressures during currency crises and thus to enhance IMF credibility. However, for the promoters of this socalled ex ante approach, conditionality should be limited only to short-term credits issued by the IMF during a liquidity crisis.

The public choice approach to conditionality raises two questions (and has two drawbacks). First, in restricting ex ante conditionality to short term credits, is omits the question of structural conditionality. Despite intense debates about the opportunity to transfer this

\footnotetext{
${ }^{15}$. Vaubel (1991) has made a similar suggestion.

16. IMF Press Release, no. 03/207, November 26, 2003.
} 
conditionality to development agencies (such as the World Bank) ${ }^{17}$, structural conditions remain very important in the programs of the IMF. At present structural conditionality exerts a strong influence on institutional changes in countries under IMF supported-programs. Second, and more importantly, as we will explain below, both ex post and ex ante conditionality have to deal with the domestic institutional changes accompanying lending to recipient countries. Public choice theory proposes only a partial study of the institutional dimension of IMF conditionality. Indeed, as conditionality inefficiencies are limited to the running of the IMF itself and to the evaluation of the incentives schemes, the public choice view shares the same inconsistency with the IMF when considering the institutional component of conditionality.

We believe that taking into account these institutional changes is a necessary condition for understanding the circumstances required for improved intervention on the part of the IMF. Contrary to what the Advisory Commission has said, such analysis will not lead us to a rejection of any kind of long-term structural conditionality on the part of the IMF18. On the contrary, this type of conditionality is useful in promoting structural reforms in developing countries in order to enable them to adapt their economies to the globalization process. The problem for the IMF then is not only one of modifying the incentive mechanisms, but also of considering what reforms might be suitable given the subsequent process of domestic institutional change foreseen. From this perspective, structural conditionality does not necessarily need to be tied to lending. The following section is dedicated to this issue.

\section{Towards an Austrian Theory of IMF Conditionality Failures}

In any explanation of economic development as well as of the difference in performance of economies over time, the importance played by institutional change is scarcely controversial. (Rodrik, 2005) (North, Weingstat 1989). More precisely even if growth without good institutions might be possible, sustainable growth requires major institutional change along with the implementation of institutional functions the objectives of which are to create, regulate, stabilize and thus legitimize markets (Rodrik, 2005). Having established this point, however, it begs the question as to how such a goal can be reached especially in low-income countries. The question has aspects sides to it. The first refers to the financial capacity of countries to invest in their institutional architecture. The second refers to the implementation

\footnotetext{
${ }^{17}$. As suggested, among others, by the Advisory Commission.
} 
process itself. Here, IMF conditionality is required to play a major role. This section thus returns to the issue of the structural conditions attached to IMF programs. Drawing on the Austrian perspective concerning the critical role of institutions in the market process, we explain why conditionality may jeopardize the institutional order of recipient countries (3.1). This analysis leads us to criticize traditional proposals for the reform of conditionality (3.2). Alternative proposals are made for improving conditionality. The cornerstone of these proposals consists of redesigning the relationship between the recipient countries confronted by the need for major institutional changes, and the IMF. Such an evolution implies a transformation of the role of the IMF. (3.3).

\subsection{Institutions, Institutional Changes and Conditionality}

Let us recall that an institution is usually defined as "a regularity in social behavior that is agreed to by all members of society, specifies behavior in specific recurrent situations and is either self-policed or policed by some external authority” (Schotter, 1981: 11). This definition requires consideration not only of the legal framework, but also of regular behavioral practices associated with a set of rules, norms and routines. These two elements may influence both the emergence and evolution of institutions.

Institutions also represent a means by which agents, who are ignorant of each other's actions and expectations, obtain information that enables them to co-ordinate with each other. In other words, they represent nothing more and nothing less than a necessary condition for the running and development of markets (O'Driscoll, Rizzo, 1996) ${ }^{19}$.

Modifying the institutional structure of any economy is consequently not only complex but likely to induce some profound and not necessarily foreseen or appropriate economic changes. This is the case when implementing conditionality. Structural conditionality imposes domestic institutional changes. This is so even though the IMF has tried to reduce the number of structural conditions in its new programs. The structural benchmarks (SBMs) that focus on qualitative indicators, going beyond the traditional quantitative indicators of the IMF, have

\footnotetext{
${ }^{18}$. Adopting a different perspective, Willett (2003) suggests separating IMF programs into two major categories: a short-term facility with ex ante conditionality, and structural conditionality.

19. This argument naturally rests on the idea that the knowledge disseminated by institutions is of a stabilizing nature, in that it reaffirms the stability of the social structure at regular intervals, unlike that disseminated by the price system, which is of a dynamic nature in that it leads individuals to revise their plans continually (Hayek, 1945).
} 
followed the same development (IMF, 2001a) ${ }^{20}$. More fundamentally, it is increasingly obvious that every IMF action, the main intent of which is to obtain macroeconomic equilibrium, is never without consequences with respect to the institutional structure of a recipient country, even if the IMF tries to concentrate the majority of structural conditions on a relatively small number of sectors ${ }^{21}$.

The analysis of structural conditionality thus requires that we specify the conditions required for the recipient country's institutional order to have coherence. More precisely, such analysis must enable us to solve three interrelated problems.

Firstly, we formulate the issue of the institutional order and its unity. If the complementarity of institutions is what builds the institutional order of a society, the purpose then is to identify the forces that encourage integration, as well as the circumstances under which these forces cease to work. The distinction between 'designed institutions' and 'undesigned institutions' (Lachmann, 1970) is crucial here. The former, which include legal norms, are "the products of legislation and other manifestations of the 'social will'” (Lachmann, 1970: 69), while the latter are spontaneous entities, understood as "recurrent patterns of conduct” (ibid.: p.75). According to Lachmann's logic, while not all institutions assume the same status and function, they do, nevertheless, share the attribute of flexibility linked to the permanency of the whole. The matter now arising is how to make institutional change and structural permanence compatible, as it is not so much the change per se which gives rise to problems here, but rather unexpected change ${ }^{22}$. Conditionality should not be implemented without

\footnotetext{
20 "SBMs are indicators which aim to delineate the expected path of reform for individual structural policy measures and that can facilitate the evaluation of progress for these actions. Because many structural policies cannot be expressed in quantitative form, structural benchmarks are usually expressed qualitatively; for example, if the program calls for privatization of the state-owned telephone company, submitting the privatization bill to the legislature by date $\mathrm{x}$ could be one structural benchmark. Failure to meet structural benchmarks conveys a negative signal but does not automatically render a country ineligible to draw; instead, a decision about eligibility would be judgmental and would likely be made in a broader mid-year program review -itself an instrument of conditionality- with an eye toward the country's overall progress on the structural front” (IMF, 2000c).

21 "The majority of structural conditions -between a half and two thirds- have been, and continue to be, concentrated in a relatively small number of sectors that are at the very core of the Fund's involvement in member countries: exchange and trade systems, and fiscal and financial sectors. The relative importance of these sectors has changed, with reforms in the exchange and trade system now playing a smaller role and the financial sector a more important one than in the early 1990s. In addition, public enterprise restructuring and privatization -in part motivated by fiscal considerations- have accounted for about one fifth of the structural conditions in Fund-supported programs. Nevertheless, while a large part of structural conditionality has focused on a relatively small number of sectors that are closely linked to stabilization and external adjustment, this does not guarantee that structural reforms have always been adequately prioritized nor does it imply that too broad a reform agenda has never been an issue” (IMF, 2001a).
}

${ }^{22}$. Only this latter type of change is likely to disrupt some plans in the course of action. 
taking into account its effects on institutional complementarity, that is on the institutional order of the affected country.

Secondly, the distinction between induced and imposed institutional change (Lin, 1989) must be considered. An induced institutional change refers to the modification or replacement of an existing institution or the emergence of a new one that is voluntarily initiated and executed by an individual or a group of individuals in response to profitable opportunities. An imposed change, in contrast, is introduced and executed by an authority following its own rationale. The main point here is that institutional changes accompanying the IMF's programs are often imposed and rarely induced. The consequence is that conditionality may be conducive to a deterioration of agents' economic performances compared with the initial situation.

Thirdly, we must not forget that institutional change takes time. Indeed, the transformation of existing institutions, as in the creation of new institutions, is subject to delays: delays of implementation in the first instance, and delays of construction in the second. Yet the amount of economic change possible per unit of time is always limited because agents have limited training capacities. Indeed, given a theoretical or practical scenario, in which an economic or political authority -in this case the IMF- decides to put into place new institutions, via conditional Fund-supported programs, the benefits expected from this type of measure are debatable. The reason is that, insofar as such a policy is, by definition, limited to designed institutions, its success depends on the capacity of these new elements to meet the demand for change in institutions not yet designed. The difficulty lies in the fact that, although the transformation of designed institutions is, in general, both radical and speedy, that of nondesigned institutions is of an incremental nature and is necessarily subject to path-dependent constraints. "Various institutions and social expectations change at different speeds, particularly when there is a mix of exogenous and endogenous forces, as when global markets interact with domestic policies [...].The central problem to be addressed [...] is variable institutional adaptation” (Jacobs, 1999: 8). Yet in all cases, the time horizon of any structural program, that is the time horizon of conditionality, is radically different from that necessary for implementing the required institutional change.

Solving these three issues comes down to providing a solution to the so-called permanencyflexibility dilemma that any emerging and low-income economy faces. The issue is thus how to make institutional change and structural permanence compatible. Even if not all institutions assume the same status and function, they all share the attribute of flexibility linked to the permanency of a whole. The permanence of the overall institutional order does not involve the 
permanency of each part. But how can the need for coherence and permanence be reconciled with the need for flexibility, especially for low-income countries? The potential solutions are of primary importance in indicating what the role played by the IMF should be, more precisely in pointing to a transformation of its role beyond that of imposing so-called ex ante conditionality.

\subsection{Reform of Conditionality : A Critical Review of Traditional Solutions}

Proposals relating to the reform of conditionality focus on the necessity of strengthening the ownership of programs. This is a result of the strong correlation between successful completion of measures and the degree of ownership ${ }^{23}$. Ownership is a multidimensional concept (World Bank, 1992). First, it refers to the extent to which planned reforms in programs have been locally or externally initiated. Second, it is based on the idea that intellectual conviction as to the appropriateness of measures, matters. Finally, the degree of support from top political leadership appears to be a determinant of ownership ${ }^{24}$. Two complementary approaches to conditionality reform aim to strengthen ownership.

The first approach establishes that the efficacy of conditionality could be improved by means of a more flexible approach ${ }^{25}$. Some critical of IMF-programs consider that the penalties attached to the current conditionality are unsatisfactory. In principle, a program that has failed to be completed is penalized based on what the initial overall measures agreed to have been. Thus, implicitly, the relationship between the IMF and the recipient countries follows a "takeit-or-leave-it” logic. Such a penalty scheme lacks flexibility if one considers the obligation that a country comes under to implement both macroeconomic adjustments and structural reforms. In effect, waivers introduce a degree of flexibility into IMF-programs. Under this scheme, the IMF agrees not to interrupt a program, even in cases of non-observance of performance criteria, if it considers that the program will eventually be successfully implemented. Under these circumstances, IMF-supported programs could be considered dynamic and flexible. But, as stressed by the IEO (2005b), flexibility linked to waivers is not necessarily a satisfactory situation, but rather reflects “unrealistic expectations” (IEO, 2005b:

\footnotetext{
${ }^{23}$. Numerous empirical studies have established this relationship. See Collier et al. (1998).

${ }^{24}$. IMF defines ownership as follows: "ownership is a willing assumption of responsibility for an agreed program of policies, by officials in a borrowing country who have the responsibility of formulating and carrying out those policies, based on an understanding that the program is achievable and is in the country's own interest" (IMF, 2001b: 6).
} 
10). A more genuinely flexible procedure could be one based on a disaggregated reform package and a floating tranche. In this vein, Leandro et al. (1999), and in a similar approach Collier et al. (1997), propose to divide reform packages into several reform areas, each of them being the object of specific conditionality and monitoring. The aim is to be able to devise a penalty that is more proportional to the initial lapse in implementation. The floating tranche approach, supported by Khan and Sharma (2006), would allow each country to implement structural reforms at their own speed without putting the receipt of funds into question if a section of reforms has or has not been completed. The proposal is that the IMF would disburse credits (called floating tranches) in proportion to the adoption of structural reforms specified in the initial agreement. But only the usual quantitative performance criteria would be the object of conditionality.

Furthermore, the development of a flexible approach implies that the IMF would need to be engaged in intensive and informal policy dialogue with the recipient country. The views of government, political leaders, trade unions and members of civil society would all need to be taken into account. As explained by Collier et al. (1998), the IMF has to develop "a more systematic mechanism for providing ex post support for country-initiated, or home-grown, programs” (p.22). Three implications are inferred from this new strategy. First, resident missions in recipient countries could have more authority. Second, the IMF should allocate more resources and time in order to improve their understanding of countries' political constraints. Finally, a greater degree of initiative could be given to domestic authorities during the negotiation of the program in order to give the process more credibility, implying the need for more flexible behavior on the part of IMF $\operatorname{staff}^{26}$.

A second approach, adopted by the IMF, is to streamline structural conditionality. Taking into account the poor performance of its recent programs, the IMF is trying to reduce the number

\footnotetext{
25. A detailed presentation of this approach is beyond the scope of this paper. See, among others: Leandro, Schafer and Frontini (1999); Collier et al. (1997); Collier, Gunning and Hamada (1998); Khan and Sharma (2006).

${ }^{26}$. In 1999, the IMF and the World Bank initiated the Poverty Reduction Strategy Papers which give a greater degree of initiative to governments in low-income countries. Indeed, PRSPs are prepared by governments according to a participatory process involving domestic stakeholders. A PRSP describes the macroeconomic, structural and social policies and programs adopted by a country for several years (IMF 2003a). In August 2006, 78 countries were eligible for the poverty Reduction and Growth Facility. The last IMF available review (September 2005) shows that 49 full PRSPs have been circulated to the Fund Executive Board and an additional 11 countries have completed "interim" PRSPs. Although it is too early to evaluate them, preliminary assessments have stressed the participatory gap after the adoption of the programs and the conflicts between their multiple objectives, revealing the difficulty in adopting a clear priority order. For an external evaluation of PRSP, see Killick (2002) and I.E.O (2005a); for an internal evaluation, IMF (2003b).
} 
of structural conditions reform in order to concentrate its attention on structural reforms that are "critical" to the achievement of macroeconomic targets. The new conditionality guidelines follow three principles. First, IMF conditionality has to cover structural conditions which are “critical” to the success of the program's macroeconomic objectives. Second, structural reforms, which are not critical but "relevant" to the program's macroeconomic objectives, and which, at the same time, fall within the IMF's core areas, can possibly be subject to conditionality. Finally, conditionality would not apply to structural reforms which are not critical and fall outside the core areas of the IMF's responsibilities, even if they were macrorelevant. Here, the main difficulty is to define the threshold of what is considered critical. According to the IMF, "critical importance means that excluding the condition would seriously threaten the achievement of the program's goals or the Fund's ability to monitor implementation [...]. Determining which measures are critical is inherently an element of judgment” (IMF, 2003a). In the IMF review of the 2002 Conditionality guidelines (IMF, 2005a), two main trends are revealed. On the one hand, the share of structural conditions in non-core areas fell by 17-18 percentage points in both GRA-supported programs and PRGFsupported programs. On the other hand, while PRGF-programs exhibit a significant decline of the average number of structural conditions (from 17-18 to 13-14 percentage points in the late 1990s), in GRA-programs this average number instead increased in recent years. These results indicate "substantial differences between the aspirations of the Fund's management and the actual changes so far achieved” (Killick, 2002: 2). They reflect also the ambiguity and imprecision of the IMF targets due to divisions inside the Executive Board as to how far the reduction in structural conditionality should go. The staff has taken advantage of these divisions to resist the streamlining of the conditionality process (I.E.O., 2005b).

Even if all the previous approaches might represent progress in improving IMF conditionality, they are not necessarily an appropriate response to the problem of institutional change implied by structural conditionality. The main challenge consists in responding to new concerns encountered as a result of the globalization of markets, mainly through ensuring compatibility between domestic and global goals. Indeed, globalization goes hand in hand with the standardization of market processes. And, as we have explained, the IMF becomes a key player in such a process with its new function of facilitating the development of markets in developing countries in accordance with both global standards and domestic constraints. 


\subsection{A new Form of Conditionality}

The difficulty consists in the IMF developing its actions around two complementary temporal horizons. The first, encompassing crisis management as well as prevention, requires shortterm actions using traditional tools such as emergency lending and macroeconomic conditionality. Here one finds the IMF in its traditional role, i.e. that of financial backer, and hence with this, the traditional concept of conditionality. The second refers rather to a medium and long-term horizon implying action oriented towards development issues, such as the development of market processes. This second horizon requires the IMF to develop its mandate as adviser to countries confronted by the globalization process. Here, institutional factors play a crucial role. The point we are making, however, is that, when not explicitly taken into account, these two functions may contradict one another. The confusion arising between the requirements of these two horizons is especially relevant in two situations: when member countries are confronted by financial crises on the one hand; and when institutional weaknesses are significant in countries under IMF-programs on the other hand.

The Asian crisis is a striking example of the first situation. In 1997, the IMF concluded unprecedented emergency lending agreements with Thailand (August, \$ 17 billion), Indonesia (November, \$ 35 billion) and Korea (December, \$ 57 billion). These agreements had a similar basic design. This consisted of a mix of traditional conditionality, based on loans to the central bank and government for the repayment of debts and the stabilization of exchange rates, and on a macroeconomic framework promoting restrictive fiscal and monetary policies. At the same time it included structural conditionality focusing on a restructuring of the financial sector and on good governance measures (transparency, dismantling of monopolies, elimination of directed lending, growing role of financial markets). According to the IMF, this strategy was appropriate in order to re-establish confidence in the financial markets ${ }^{27}$. Indeed, the Fund considered that the vulnerabilities of the financial and corporate sectors were attributable to governance and market discipline deficiencies. In fact, the main purpose of the strategy was to transfer governance principles long adopted in Western advanced economies. However, these programs were not only ineffective in preventing exchange rate depreciations, but they also exacerbated instability (Radelet, Sachs, 1998). In a crisis situation, and subsequently within a very short-term horizon, structural conditions imposed by the IMF,

\footnotetext{
${ }^{27}$. For instance, see Lane et al. (1999); Baliño et al. (2000).
} 
particularly after the Asian crisis, were aimed at profoundly modifying the domestic institutions of economies thereby provoking economic destabilization.

Countries where rule of law and institutional quality are the weakest often belong to the category of low-income countries ${ }^{28}$. The IMF (2004) recognizes four areas of work with lowincome member countries: (i) policy advice; (ii) capacity building; (iiii) financing and debt relief; and (iv) implementation of the Millennium Development Goals (through the Monterrey Consensus). Capacity building is especially important for our purposes. The IMF uses different tools in order to strengthen the institutional architecture in low-income member countries (Hakura, Nsouli, 2003). The report of the observance of standards and codes (ROSCs) allows the IMF to promote the adoption of standards in 11 areas grouped into three categories: (i) transparency standards; (ii) financial sector standards; and (iii) market integrity standards for the corporate sector. IMF staff members work with domestic authorities to identify financial sector vulnerabilities and to provide technical assistance through the financial sector assessment program (FSAP).

Whatever the situation -financial crisis or institutional weakness- the IMF structural conditionality suffers from the same drawback: the "one-size-fits-all” approach consisting of transplanting the institutional architecture of mature countries to emerging and developing countries. This approach contradicts recent lessons suggested by the literature on the impact of reforms on growth ${ }^{29}$. Rodrik (2005) stresses that “principles such as appropriate incentives, property rights, sound money, and fiscal solvency all come institution free [...]. There may be multiple ways of packing these principles into institutional arrangements”. For example, China has experimented with a heterodox way of achieving the above principles, while Latin American countries have adopted the Washington Consensus principles based on an orthodox concept. In terms of growth performances, the two groups of countries have experienced contrasting outcomes: a strong performance for China, but poor for Latin American countries. In an empirical study, Berkowitz et al. (2003) show the inefficiencies engendered by the transplantation of formal legal frameworks originating in Western countries to other countries. The I.E.O. (2005c) stresses that the effectiveness of the technical assistance provided by the IMF "has been undermined by a lack of awareness of institutional, organizational, or managerial features of the recipient country” (p.11). Financial reforms in

\footnotetext{
28. For an overview of the relationship between low-income countries and IMF, see for instance Lombardi (2005); Martin and Bargawi (2005).

${ }^{29}$. See the recent World Bank study (World Bank, 2005) and Rodrik (2006).
} 
emerging markets underestimated the weight of asymmetric information in such economies. In this context, banks play a major role to favor the development of contractual practices (Allegret, Dulbecco, Courbis, 2003). When the international financial institutions promote financial liberalization, it is necessary to bear in mind the fact that such measures alone cannot lead to new financial systems in which market mechanisms are expected to play an important role. The implementation of new legal regulations by authorities does not necessarily lead to the acquiescence of institutions. Indeed, they must be adopted by private agents. In other words, promoting banking reforms, in which the main objective is to encourage banking practices in emerging economies that will converge with practices adopted in numerous mature markets, is not necessarily the most efficient way to promote economic growth. Interpersonal relationships are less prominent in developed countries because of the presence of liquid financial markets with strong legal rules and contract-enforcement mechanisms. Overall, empirical findings confirm our analytical framework: institutional reforms are part of a long-term process that must take into account specific domestic circumstances. Successful reforms must be country-specific and not based on a global and uniform concept of the working of the market economy.

What are the implications for the conduct of IMF structural conditionality? The IMF has to resolve two difficulties in its interventions in developing countries. The first is the time horizon of its policies. On the one hand, structural conditionality requires a long-term perspective with delays in reform implementation and path dependency constraints. On the other hand, IMF lending is by nature short term, focused mainly on 3 year programs. These timings are not compatible with each other. Second, the confusion between its two functions policy adviser, especially on matters of institutional reforms, and financial backer- is subject to conflicts of interest, which undermine IMF efficacy. In order to strengthen the effectiveness of the IMF, it seems to us necessary to disentangle these two functions and allow IMFsupported programs including structural conditionality to have longer time horizons. From this perspective, a reform of conditionality should proceed along two main steps. The first is a general application of the policy support instrument (PSI). This new instrument allows member countries to benefit from IMF staff advice without Fund financial assistance. The main purpose of the PSI is "to help low-income countries members in designing and pursuing policies that meet high standards, and to signal the strength of these policies” (IMF, 2005h: 5). Policy dialogue between the Fund and member countries is more intense and frequent under this arrangement than with the Article IV consultations framework. The PSI is based on 
the member's poverty reduction strategy and includes areas such as financial sector reform, transparency, and strengthening institutions. At present, PSIs are exclusively dedicated to “mature stabilizers", i.e. to countries who don’t need IMF assistance ${ }^{30}$. Furthermore, the duration of these programs remains too short ${ }^{31}$ with regard to the objectives of institutional reform that they contain. It seems to us that the Policy Support Instrument should be generalized to all developing countries involved in IMF-programs in which institutional reform is implied. A second step in the reform of IMF conditionality is to endow the IMF with tools that would allow it to take better account of the specific domestic circumstances of every member country. In 2004, the IMF created a new instrument for low-income countries that emphasizes the distributional impact of major macroeconomic and structural reforms: the Policy and Social Impact Analysis. We propose to create a similar instrument focusing on the institutional impact of IMF-programs.

\section{Conclusion}

In this paper, we have stressed the failures of IMF conditionality, focusing on structural conditionality. The IMF must build a new approach to structural conditionality in order to safeguard the coherence of the institutional order in recipient countries. Conditionality implies institutional change and institutional change is a very complex process which cannot be managed through so-called ex ante conditionality. An alternative solution should not consist of rejecting such change but rather, dealing with its complexity and diversity head on. The analytical framework proposed should help to evaluate both the institutional component of conditionality and the necessary evolution of the role of the IMF. Indeed we suggest a separation of the role of the IMF as financial backer from its role as adviser to countries confronted by the globalization process ${ }^{32}$. From our perspective, the role of the Fund could be (taken over by?? Presumably there is no one to take over the lending role of the IMF but external advisers or consultants could take over the advisory role that IMF staff currently play?) that of an external adviser or consultant in order to take into account the specific circumstances of each country in a global context. By global context, we refer to the new constraints implied by the globalization process that tend to impose a standardized set of behaviors. The evolution of conditionality proposed in this paper would imply that each

\footnotetext{
${ }^{30}$. Nigeria has been the first IMF-member to use PSI in October 2005.

31. The duration is between one year and three years with a maximum of four years.

${ }^{32}$. Bevan (2005) voices several doubts regarding the traditional link between policy advice and financing. Such a separation could apply to the World Bank too. On World Bank conditionality, see Dreher (2004).
} 
country benefiting from the advice of the IMF should find the best trade-off between the specific characteristics of the domestic institutional order and the global market. This is for us the main challenge of globalization: that is to build coherence between global governance and domestic objectives.

\section{References}

Allegret J.P., Courbis B., Dulbecco Ph. (2003), "Financial Liberalisation and Stability of the Financial System in Emerging Markets: the Institutional Dimension of Financial Crises", Review of International and Political Economy, 10, 1, February, pp.73-92.

Baliño T.J.T., Enoch C., Gulde A.M., Lindgren C.J., Quintyn M., Teo L. (2000), Financial Sector Crisis and Restructuring: Lessons From Asia, IMF Occasional Paper, n¹88, January.

Barro R.J., Lee J.W (2005), “IMF Programs: Who Is Chosen and What Are The Effects?”, Journal of Monetary Economics, vol.52, Issue 7, pp.1245-1269.

Berkowitz D., Pistor K., Richard J.F. (2003), "Economic Development, Legality, and the Transplant Effect”, European Economic Review, vol.47, Issue 1, February, pp.165-195.

Bevan D. (2005), “The IMF and Low-Income Countries”, World Economics, vol.6, n², April-June, pp.66-85.

Collier P., Gunning JW., Hamada K. (1998), Report of the Group of Independent Persons Appointed to Conduct an Evaluation of Certain Aspects of the Enhanced Structural Adjustment Facility, IMF, Washington DC.

Dollar D., Svensson J. (2000), "What Explains the Success or Failures of Structural Adjustment Programs?”, Economic Journal, vol. 110, October, pp.894-917.

Dreher A. (2006), “IMF Conditionality: Theory and Evidence”, Paper prepared for the Independent Evaluation Office of the IMF, April.

Dreher A. (2004), “A Public Choice Perspective of IMF and World Bank Lending and Conditionality”, Public Choice, vol.119, n³, June, pp.445-464.

Dreher A. (2003), “The Influence of Elections on IMF Program Interruptions”, The Journal of Development Studies, vol.39, 6, pp.101-120.

Dreher A, Jensen N. (2007), "Independent Actor or Agent? An Empirical Analysis of the Impact of US Interests on IMF Conditions”, The Journal of Law and Economics, vol.50, Issue 1 , forthcoming.

Dreher A., Vaubel R. (2004a), "Does the IMF and IBRD Cause Moral Hazard and Political Business Cycles? Evidence from Panel Data”, Open Economies Review, vol.15, 1, pp.5-22.

Dreher A., Vaubel R. (2004b), “The Causes and Consequences of IMF Conditionality”, Emerging Markets Finance and Trade, vol.40, 3, pp.26-54.

Edwards M.S. (2001), “Sticking with Yes: Domestic Institutions and IMF Compliance”, Annual Meeting of American Political Science Association, San Francisco, September.

Goldstein M. (2000), “IMF Structural Conditionality: How Much is Too Much?”, NBER Conference on Economic and Financial Crises in Emerging Market Economies, Woodstock, Vermont, October. 
Gould E.R. (2001), "Money Talks: The Role of External Financiers in Influencing IMF Conditionality", Annual Meeting of American Political Science Association, San Francisco, September.

Hakura D.S., Nsouli S.M. (2003), “The Millennium Development Goals, the Emerging Framework for Capacity Building, and the Role of the IMF”, IMF Working Paper, WP/03/119; June.

Hayek F. (1945), “The use of knowledge in society”, in Hayek (1949), Individualism and economic order, Routledge \& Kegan Paul, London.

Independent Evaluation Office (2005a), The Poverty Reduction Strategy Initiative, Findings from Ten Country Case Studies of World Bank and IMF Support, World Bank Evaluation Department and IMF Independent Evaluation Office, Washington D.C.

Independent Evaluation Office (2005b), Draft Issues Paper for an Evaluation of structural Conditionality in IMF-Supported Programs, March, Washington D.C.

Independent Evaluation Office (2005c), Evaluation of the Technical Assistance Provided by the International Monetary Fund, January, Washington D.C.

International Monetary Fund (2001a), Conditionality in Fund-Supported Programs-Policy Issues, February, Washington DC.

International Monetary Fund (2001b), Strengthening Country Ownership of Fund-Supported Programs, December, Washington DC.

International Monetary Fund (2001c), Streamlining Structural Conditionality: Review of Initial Experience, July, Washington DC.

International Monetary Fund (2003a), Operational Guidance on the New Conditionality Guidelines, May, Washington DC.

International Monetary Fund (2003b), Poverty Reduction Strategy Papers, Detailed Analysis of Progress in Implementation, September, Washington DC.

International Monetary Fund (2004), The Role of the Fund in Low-Income Member Countries, August, Washington D.C.

International Monetary Fund (2005a), Review of the 2002 Conditionality Guidelines, March, Washington D.C.

International Monetary Fund (2005b), Policy Support and Signaling in Low-Income Countries, June, Washington D.C.

Ivanova A., Mayer W., Mourmouras A., Anayiotos G. (2006), "What Determines the Implementation of IMF-Supported Programs?”, in IMF-Supported Programs, Recent Staff Research, A. Mody and A. Rebucci (eds), Washington D.C., pp.160-186.

Jacobs S. (1999), “The Second Generation of Regulatory Reforms”, Communication to The Conference on Second Generation Reforms, IMF, November 8-9.

Joyce J.P. (2003), "Promises Made, Promises Broken: A Model of IMF Program Implementation", Conference on The Impact of Globalization on the Nation-State from Above: the IMF and the World Bank, Yale University, April, forthcoming Economics \& Politics.

Kapur D., Webb R. (2000), "Governance-related Conditionalities of the International Financial Institutions”, Group of 24 Discussion Paper Series, nº6, August. 
Khan MS., Sharma S. (2006), "IMF Conditionality and Country Ownership of Programs”, in IMF-Supported Programs, Recent Staff Research, A. Mody and A. Rebucci (eds), Washington D.C., pp.119-130.

Killick T. (2002), “The 'Streamlining' of IMF Conditionality: Aspirations, Reality and Repercussions", A Report for The Department for International Development, Overseas development Institute, London, April.

Lachmann, L. (1970), The legacy of Max Weber, Heinemann, London.

Lane T., Ghosh A.R., Hamann J., Phillips S., Schulze-Ghattas M., Tsikata T. (1999), IMFSupported Programs in Indonesia, Korea and Thailand, IMF Occasional Paper, $\mathrm{n}^{\circ} 178$, June, Washington DC.

Langlois R. (1993), "Orders and organizations: toward an Austrian theory of social institutions", in Austrian economics: tensions and new directions, B.J. Caldwell and St. Boehm (eds.),, Dordrecht: Kluwer Academic Publishers.

Leandro JE., Schafer H., Frontini G. (1999), “Towards a More Effective Conditionality: An Operational Framework”, World Development, vol.27, n², pp.285-299.

Lin J.Y. (1989), “An Economic Theory of Institutional Change: Induced and Imposed Change”, Cato Journal, Vol. 9, n¹.

Lombardi D. (2005), “The IMF's Role in Low-Income Countries: Issues and Challenges”, IMF Working Paper, WP/05/177, September.

Martin L.L. (2002), "Distribution, Information, and Delegation to International Organizations: the Case of IMF Conditionality", Cambridge Workshop on the Political Economy of International Finance and the BYU Conference on Delegation to International Organizations, September.

Martin M., Bargawi B. (2005), “A Changing Role for the IMF in Low-Income Countries”, in Fondad (ed), Helping the poor? The IMF and Low-Income Countries, The Hague, pp.68-126.

Meltzer A. (2000), International Financial Institution, Advisory Commission, March, Washington DC.

Mussa M., Savastano M. (2000), “The IMF Approach to Economic Stabilization”, in B.S. Bernanke and J.J. Rotemberg (eds.). NBER Macroeconomics Annual 1999. Cambridge, MA: MIT Press, pp. 79-122.

Nelson R., Winter S. (1982), An evolutionary theory of economic change, The Belknap Press of Harvard University Press, Cambridge, Massachusetts, and London, England.

North (1990), “A Transaction Cost Theory of Politics”, Journal of Theoretical Politics, 2, 4, pp.355-367.

O'Driscoll J., Rizzo M. (1996), The economics of time and ignorance, Basil Blackwell, London.

Radelet S., Sachs J.D. (1998), “The East Asian Financial Crisis: Diagnosis, Remedies, Prospects”, Brookings Paper on Economic Activity, n²1, pp.1-74.

Rodrik D. (2005), “Growth Strategies”, in Handbook of Economic Growth, vol.1A, P. Aghion and S. Durlauf (eds), Elsevier, North-Holland, pp.967-1014.

Rodrik D. (2006), “Goodbye Washington Consensus, Hello Washington Consensus?”, Journal of economic Literature, forthcoming. 
Schotter A. (1981), The economic theory of social institutions, Cambridge University Press, New York.

Svensson J. (2003), "Why Conditional Aid Does not Work and What Can Be Done About It?”, Journal Of Development Economics, vol.70, pp.381-403.

Thacker S.C. (1999), “The High Politics of IMF Lending”, World Politics, 52, 1, pp.38-75.

Vaubel R. (1991), “The Political Economy of the International Monetary Fund: A Public Choice Approach", in The Political Economy of International Organisations, R. Vaubel and T. Willett (eds), Boulder, Westview, pp.205-245.

Vreeland J.R. (2002), “Institutional Determinants of IMF Agreements”, Mimeo, December.

Willett TD. (2001), "Restructuring IMF Facilities to Separate Lender of Last Resort and Conditionality Programs: the Meltzer Commission Recommendations as Complements rather than Substitutes”, Claremont Colleges, Working Papers in Economics, August.

Willett TD. (2002), “Towards a Broader Public Choice Analysis of the IMF”, Claremont Colleges, Working Papers in Economics, March.

Willett TD. (2003), “The IMF and Capital Account Crises: The Case for Separate Lender of Last Resort and Conditionality Functions”, Conference on The Impact of Globalization on the Nation-State from Above: the IMF and the World Bank, Yale University, April.

World Bank (2005), Economic Growth in the 1990s: Learning from a decade of Reform, Washington D.C.

World Bank (1992), "World Bank Structural and Sectoral Adjustment Operations: the Second OED Overview”, Operations Evaluation Department Report 10870, June, Washington DC. 